\title{
Responses of Papaya to Short-term Insecticidal Oxygen Atmosphere
}

\author{
Elhadi M. Yahia, Marisela Rivera, and Omar Hernandez \\ Centro de Investigacion en Alimentación y Desarrollo, A. C., Apartado Postal 1735, Hermosillo, \\ Sonora, Mexico \\ Additional index words. Carica papaya, postharvest, anaerobic respiration, alcohol dehydrogenase, pyruvate \\ decarboxylase, lactate dehydrogenase
}

\begin{abstract}
Papaya (Carica papaya L., CV. Sunrise) fruits were exposed to a continuous flow of an atmosphere containing $<0.4 \% \mathrm{O}_{2}$ (the balance being $\mathrm{N}_{2}$ ) for 0 to 5 days at 20C. Decay was a major problem, and some fruit had developed off-flavors after 3 days in low $\mathrm{O}_{2}$ plus 3 days in air at 20C. The intolerance of the fruit to low $\mathrm{O}_{2}$ correlates with an increase in the activity of pyruvate decarboxylase and lactate dehydrogenase but not with the activity of alcohol dehydrogenase. Insecticidal $\mathrm{O}_{2}(<0.4 \%)$ atmospheres can be used as a quarantine insect control treatment in papaya for periods $<3$ days at $20 \mathrm{C}$ without the risk of significant fruit injury.
\end{abstract}

Storage of several fresh fruits and vegetables in modified atmospheres (MA) or controlled atmospheres (CA) with moderately low $\mathrm{O}_{2}(2 \%$ to $3 \%)$ and high $\mathrm{CO}_{2}(<5 \%)$ levels was shown to inhibit ethylene production/action, reduce respiratory metabolism, maintain flesh firmness and color, control some physiological and pathological disorders, and thus prolong the postharvest life of these crops (Kader, 1986). Atmospheres containing $<1 \% \mathrm{O}_{2}$ and/or $>60 \% \mathrm{CO}_{2}$ have been reported to be lethal to several insects (Brandl et al., 1983; Gaunce et al., 1982; Ripp, 1984). In addition to being cost competitive as an alternative to chemical fumigation (Soderstorm et al., 1984), CA/MA leave no chemical residues on the fruit. Commercial use of CA/MA for insect control in grain storage has been reported (Ripp, 1984). The time required to control insects with MA and CA depends on the species of the insect, its life stage, the composition of the atmosphere, temperature, and relative humidity (RI-I). Most stored gain insects are controlled in $\approx 4$ days by atmospheres containing $<1 \% \mathrm{O}_{2}$ and/or $>60 \% \mathrm{CO}_{2}$ at > 20C (Brandl et al., 1983; Ripp, 1984; Soderstorrn and Brandl, 1984). Research on the use of MA/CA for insect control in fruits and vegetables has been very limited. Treatments of European red mite on 'Delicious' and' 'Spartan' apples (Malus domestics Borkh.) with close to $100 \% \mathrm{CO}_{2}$ or $\mathrm{N}_{2}$ at $21 \mathrm{C}$ to $24 \mathrm{C}$ provided $100 \%$ control in 2 days (Gaunce et al., 1982). A mixture of $60 \% \mathrm{CO}_{2}$ in $\mathrm{N}_{2}$ was equally effective. Adult sweetpotato weevils, Cylas formicarius elegantulus (Summers), were killed in $\leq 1$ week by $8 \%$ to $10 \% \mathrm{O}_{2}$ plus $30 \%$ to $60 \% \mathrm{CO}_{2}$ in $\mathrm{N}_{2}$ at $30 \mathrm{C}$ and 75\% RH (Delate et al., 1990).

Most papaya-growing regions in Mexico are infested with several insects, including various species of the fruit fly. There is no established quarantine procedure for this fruit in Mexico (especially for export to the United States) since the banning of ethylene dibromide fumigation. Concentrations of methyl bromide effective against fruit flies at ambient temperature were found to damage papaya (Couey and Hayes, 1986). A two-stage hot water dip treatment was adopted as a quarantine procedure for Hawaiian papaya destined for export (Couey and Hayes, 1986). However, this treatment is limited to specific ripening stages of the fruit, and in some cases has caused damage (Couey, 1989). In addition, viable larvae of the oriental fruit fly (Dacus

Received for publication 11 Feb. 1991. Accepted for publication 12 Sept. 1991. The cost of publishing this paper was defrayed in part by the payment of page charges. Under postal regulations, this paper therefore must be hereby marked advertisement solely to indicate this fact. dorsalis Hendel) were found after treatment in fruit with blossom-end defects (Zee et al., 1989).

Potential exists for successful application of CA for insect quarantine treatments. However, very low levels of $\mathrm{O}_{2}$ and very high levels of $\mathrm{CO}_{2}$ can induce a shift from aerobic to anaerobic respiration. The anaerobic compensation point (ACP) for mature green 'Bartlett' pears (Pyrus communis L.) at $25 \mathrm{C}$ was found to be $1.6 \%$ to $1.7 \% 0_{2}$; it decreased to $\approx 0.3 \% \mathrm{O}_{2}$ as the temperature decreased to 0C (Boersig et al., 1988). Levels of $0_{2}$ below the ACP for prolonged periods increase the accumulation of acetaldehyde and ethanol and are detrimental to the quality of fresh fruits and vegetables. Acetaldehyde and ethanol are formed from pyruvate via pyruvate decarboxylase (PDC; EC 4.1.1.1) and alcohol dehydrogenase (ADH; EC 1.1.1.1), respectively. $\mathrm{L}(+)$ lactate has also been shown to accumulate under anaerobic conditions in various plants, and is formed from pyruvate via lactate dehydrogenase (LDH; EC 1.1.1.27) (Davis, 1980).

The objective of this work was to determine the tolerance of papaya to 0 , levels that have potential for insect control and to study the effects of this treatment on levels of intermediates and activities of enzymes of anaerobic respiration.

\section{Materials and Methods}

Papaya fruits were obtained from the wholesale market at Hermosillo, Sonora, Mexico. Immediately upon arrival at the laboratory, fruits were washed in chlorinated (300 ml-liter ${ }^{-1}$, water at room temperature, dried, sorted, and matched by color and size. Only fruits free of defects and weighing 250 to $350 \mathrm{~g}$ were used. Twenty fruits were individually placed in 3.8-liter glass jars at $20 \mathrm{C}$ and ventilated with humidified air free of $\mathrm{C}_{2} \mathrm{H}_{4}$ and $\mathrm{CO}_{2}$ at $200 \mathrm{ml} \cdot \mathrm{min}^{-1}$ for respiration measurements. Air flow was controlled with a flow board and capillary tubing. A sample of 30 fruits was evaluated for external appearance, flesh firmness, and internal quality.

The rest of the fruits were stored either in air at $20 \mathrm{C}$ or exposed to a continuous flow of an atmosphere containing $<10.4 \%$ $0_{2}$ at a rate of $200 \mathrm{ml} \cdot \mathrm{min}^{-1}$ for up to 5 days at $20 \mathrm{C}$. The low $\mathrm{O}_{2}$ atmosphere was obtained by mixing $\mathrm{CO}_{2}$-free air and $\mathrm{N}$, and was humdified before entering the jars. Gas samples were taken every day to verify the resulting atmosphere and for respiration measurements. Oxygen content was measured with a portable $\mathrm{O}_{2}$ analyzer (Mocon LC 700F, Modern Controls, Minneapolis) and $\mathrm{CO}_{2}$ content by an infrared analyzer (Horiba PIR 700, Hor- 


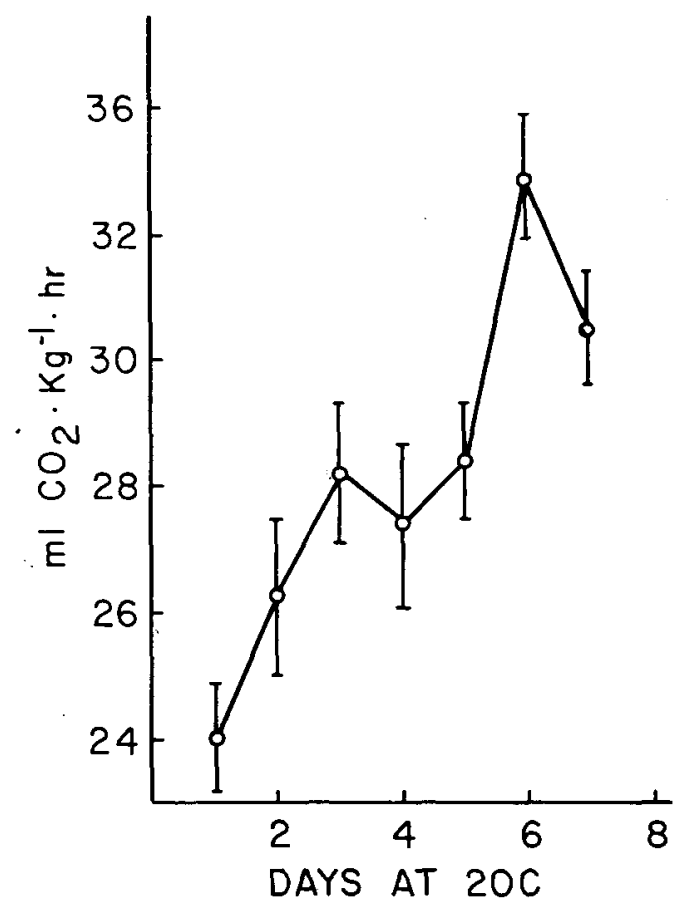

Fig. 1. Respiration rate of papaya in air at 20C. The vertical bars represent the SE of the mean.

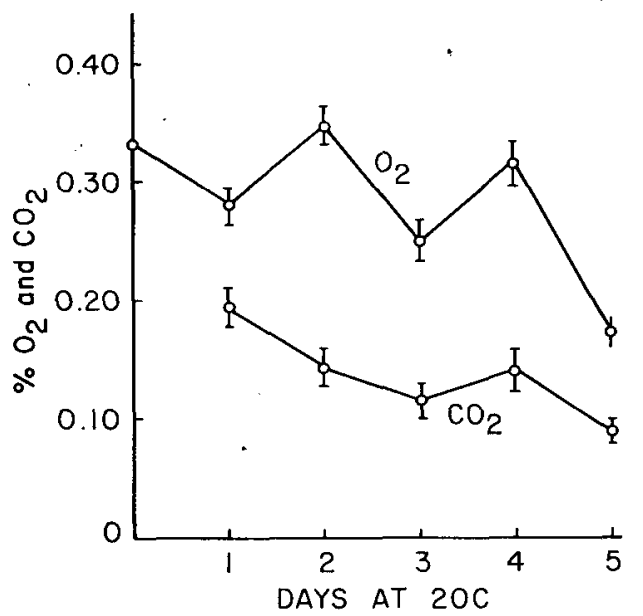

Fig.2. Changes in $\mathrm{O}_{2}$ and $\mathrm{CO}_{2}$ concentration during low- $\mathrm{O}_{2}$ storage of papaya at $20 \mathrm{C}$. The vertical bars represent the SE of the mean.

iba Instruments, Irvine, Calif.). Air-stored fruits were placed in a corrugated box wrapped in a low density polyethylene bag with enough holes to maintain a nonmodified but humid $(80 \%$ to $85 \% \mathrm{RH})$ atmosphere. Half of the fruits (12 fruits per treatment) from normal and low- $\mathrm{O}_{2}$ atmospheres were evaluated every day (immediately after removal from low $\mathrm{O}_{2}$ atmosphere), and the other half was transferred to air at 20C and evaluated after 3 days. During each evaluation, three fruits per treatment were immediately frozen for analysis of the substrates and enzymes of anaerobic respiration, while the rest of the fruits were evaluated for external appearance, incidence of decay, flesh firmness, internal appearance, and presence of off-flavors. Fruits were checked for external injury and incidence of decay and tested for flesh firmness on six points of each fruit (skin removed) using a firmness tester (Chatillon DFG 50, John Chatillon \& Sons, New York) with an 8-mm tip. Fruits were halved and immediately smelled and tasted by the authors to detect off-

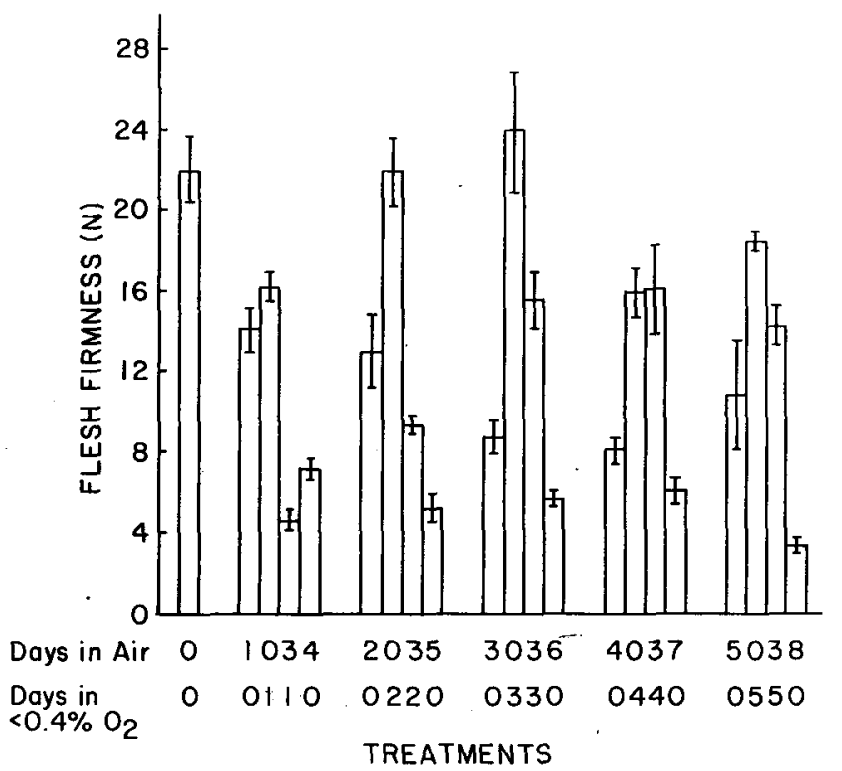

Fig. 3. Flesh firmness of papaya stored in air for $\mathrm{O}$ to 8 days, or in $<0.4 \% \mathrm{O}_{2}$ for 0 to 5 days, followed by 3 days in air at 20C. The vertical bars present the SE of the mean.

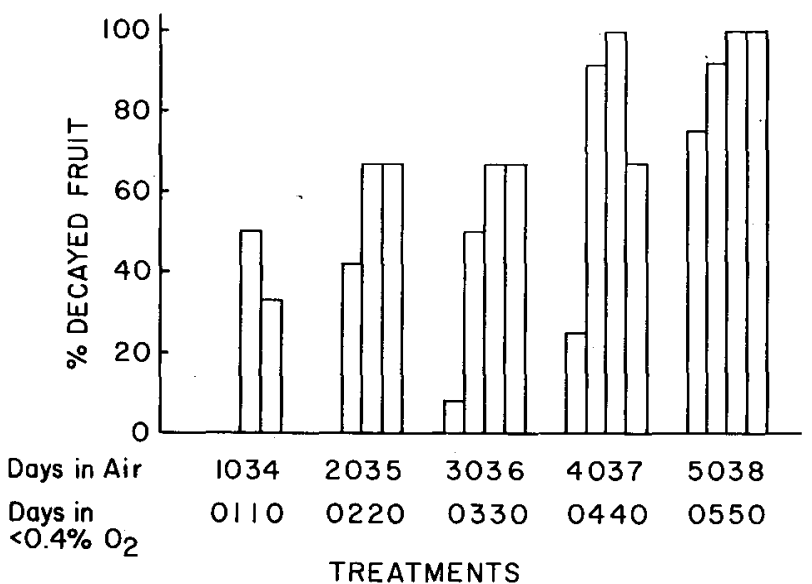

Fig. 4. Decay incidence in papaya stored in air for 0 to 8 days, or in $<0.4 \% 0_{2}$ for $\mathrm{O}$ to 5 days, plus 3 days in air at $20 \mathrm{C}$.

odors and off-flavors, and also were examined for the presence of internal injury. Frozen fruits were lyophilized and ground into a fine powder. The activity of the enzymes ADH and PDC was measured using the method reported by Chang et al. (1982). LDH activity was determined according to the method of Hoffman et al. (1986). Pyruvate and lactate were quantified by the methods of Evans and Garraway (1976) and Bucher et al. (1963), respectively. Extractable protein content was estimated according to Bradford (1976) using BSA as the standard.

\section{Results and Discussion}

Fruits used in this experiment were in their initial stage of ripening. Their respiration rate increased consistently and reached a peak after 6 days in air at 20C (Fig. 1). The $\mathrm{O}_{2}$ concentration $\mathrm{m}$ the atmosphere around the low- $\mathrm{O}_{2}$ stored fruits ranged between $0.17 \%$ and $0.35 \%$, while that of $\mathrm{CO}_{2}$ fluctuated between $0.09 \%$ and $0.19 \%$ over the 5 -day storage period (Fig. 2).

Flesh firmness decreased less in low $\mathrm{O}_{2}$-stored fruits than in the control (Fig. 3). Fruits stored in air softened rapidly as the 

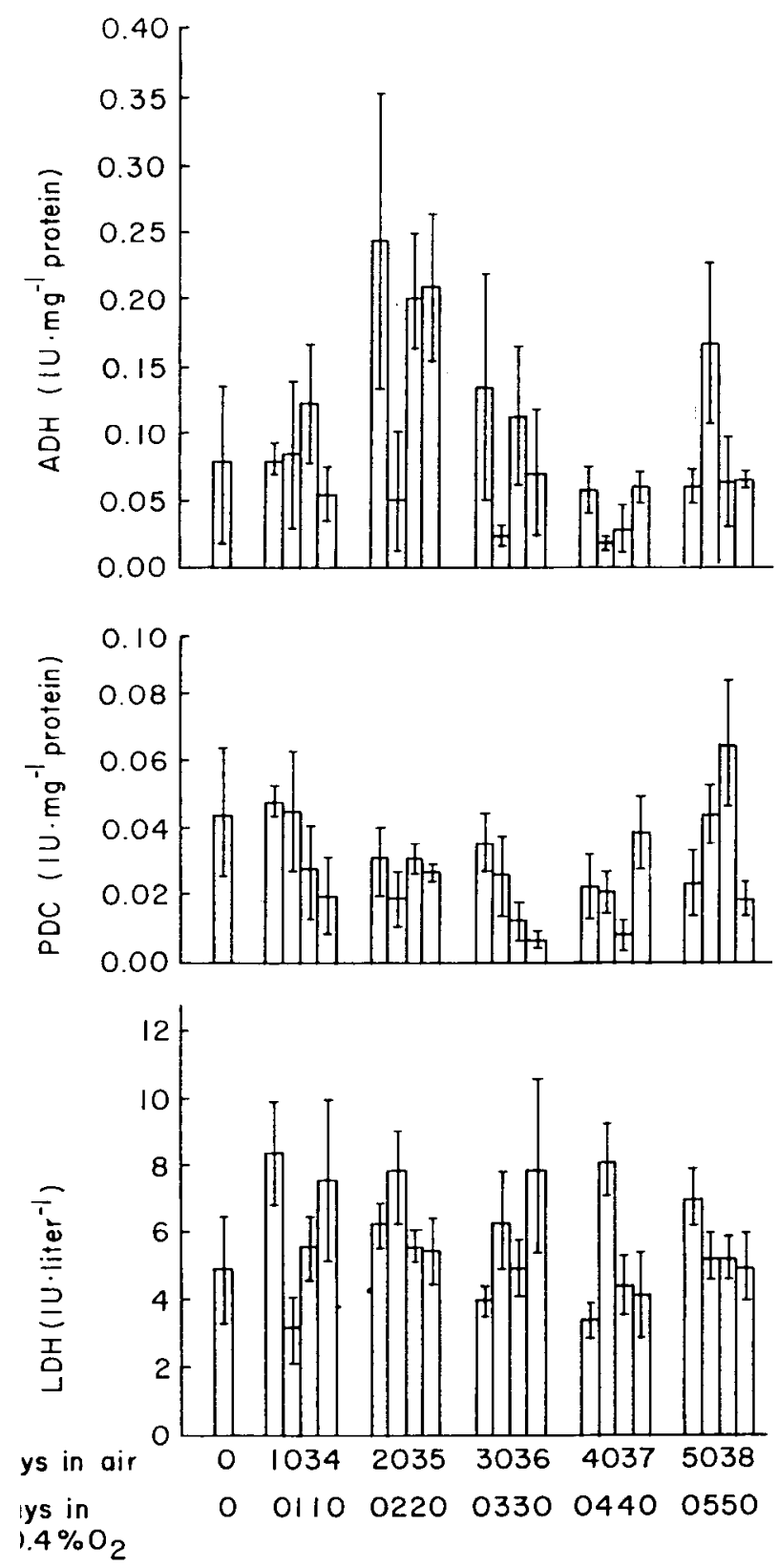

TREATMENTS

Fig.5. Activities of alcohol dehydrogenase (ADH), pyruvate decarboxylase (PDC), and lactate dehydrogenase (LDH) in papaya stored in air for 0 to 8 days, or in $<0.4 \% \mathrm{O}_{2}$ for 0 to 5 days, plus 3 days in air at $20 \mathrm{C}$. The vertical bars represent the SE of the mean.

storage period increased. Firmness of fruits exposed to low- $\mathrm{O}_{2}$ atmosphere decreased less as the exposure period to low $\mathrm{O}_{2}$ increased. Fruits stored in air for 3 days following exposure to low $\mathrm{O}_{2}$ for $\geq 3$ days maintained relatively firm flesh. There was no apparent external or internal low- $\mathrm{O}_{2}$ injury. However, $30 \%$ of the fruits emitted very weak abnormal odors after 3 days in low $\mathrm{O}_{2}$ plus 3 days in air, and the intensity of these odors increased as the exposure period to low $\mathrm{O}_{2}$ increased.

Decay was more common in fruits stored in low $\mathrm{O}_{2}$ than in the control (Fig. 4). Decay was evident after 1 day in low $\mathrm{O}_{2}$ plus 3 days in air, and increased with longer exposure to low $0_{2}$. Although no microbiological identification was performed, most of the decay appeared to be stem end rot and anthracnose (Alvarez and Nishijima, 1987). The higher incidence of decay in low $\mathrm{O}_{2}$-stored fruits compared with that of the control may have been due to the high humidity in low $\mathrm{O}_{2}$ storage rather than an effect of low $\mathrm{O}_{2}$, but this aspect was not tested. Low $\mathrm{O}_{2}$ alone appears to be insufficient for decay control in papaya. Future studies with insecticidal low- $\mathrm{O}_{2}$ atmospheres in papaya should include decay control treatments.

The levels of $\mathrm{O}_{2}$ and $\mathrm{CO}_{2}$ required to control insects are outside the range of tolerable atmospheres reported for longterm storage of fruits and vegetables (Kader and Morris, 1977). When exposure time is short, some horticultural crops might tolerate these extreme atmospheres (Delate and Brecht, 1989; Ke et al., 1990; Yahia et al., 1989). However, Smilanick and Fouse (1989) found that several nectarine cultivars had abnormal ripening, elevated ethanol and acetaldehyde content, and increased internal browning when exposed to an atmosphere containing $0.5 \% \mathrm{O}_{2}$ for 3 days at $15 \mathrm{C}$. Low $\mathrm{O}_{2}(0.1 \%$ to $0.4 \%)$ and high $\mathrm{CO}_{2}(50 \%$ to $80 \%)$ for periods $>1$ day at $20 \mathrm{C}$ resulted in substantial injury, accumulation of ethanol and acetaldehyde, and increased activity of ADH, PDC, and LDH in avocado (Persea americana Mill.) (Carrillo-Lopez and Yahia, 1991; Yahia and Kader, 1991) and pears (Yahia et al., 1991). However, mango (Mangifera indica L.) was very tolerant to atmospheres containing $0.2 \%$ to $0.3 \% \mathrm{O}_{2}$ (balance $\mathrm{N}_{2}$ ) for up to 5 days at 20C (Tiznado et al., 1990).

Low $\mathrm{O}_{2}$ for 2 to 4 days decreased the activity of ADH (Fig. 5). However, the activity of this enzyme returned to normal levels after the papaya were transferred to air. PDC activity increased slightly (compared with the control) after exposure to low $\mathrm{O}_{2}$ for 5 days but was not affected by shorter exposure periods (Fig. 5). LDH activity was lower in fruits stored in low $\mathrm{O}_{2}$ for 1 day than in the control, increased to much higher levels for fruits stored for 3 and 4 days, and was slightly higher in fruits stored in air for 5 days (Fig. 5). Fruits stored in air for 3 days following low $\mathrm{O}_{2}$ treatment for 1 to 5 days had similar levels of $\mathrm{LDH}$, and there were no differences among these fruits and those stored continuously in air. There were no differences in pyruvate and lactate levels among fruits stored in air or in the low- $\mathrm{O}_{2}$ atmosphere (results now shown).

We conclude that on the basis of off-flavor development (initiation of anaerobic respiration) papaya can only tolerate insecticidal $0_{2}(\mathrm{O} .17 \%$ to $0.35 \%)$ atmospheres for $<3$ days at $20 \mathrm{C}$. Therefore, these atmospheres can be used for papaya fruits to control insects that are killed within 2 days at 20C, without the risk of significant fruit injury. Longer exposure can induce offflavors and fruit decay.

\section{Literature Cited}

Alvarez, A.M. and W.T. Nishijima. 1987. Postharvest diseases of papaya. Plant Dis. 7:681-686.

Boersig, M.R., A.A. Kader, and R.J. Romani. 1988. Aerobic-anaerobic respiratory transition in pear fruit and cultured pear fruit cells. J. Amer. Soc. Hort. Sci. 113:869-873.

Bradford, M.M. 1976. A rapid and sensitive method for the quantification of microgram quantities of protein utilizing the principles of protein dye binding. Anal. Biochem. 72:248 254.

Brandl, D.G., E.L. Soderstorm, and F.E. Schreiber. 1983. Effects of low-oxygen atmospheres containing different concentrations of carbon dioxide on mortality of the Navel Orange worm, Amyelois transitella Walker (Lepidoptera: Pyralidae). J. Econ. Entomol. 76:828830 .

Bucher, T., R. Czok, W. Lamprecht, and E. Latzco. 1963. Pyruvate, p. 253-259. In: H. Bergmeyer (ed.). Methods of enzymatic analysis. Academic, New York.

Carrillo-Lopez, A. and E.M. Yahia. 1991. Avocado fruit tolerance and 
responses to insecticidal $\mathrm{O}_{2}$ and $\mathrm{CO}_{2}$ atmospheres. HortScience 26:734. (Abstr.)

Chang, L.A., L.K. Hammet, and D.M. Pharr. 1982. Ethanol, alcohol dehydrogenase and pyruvate decarboxylase in storage roots of four sweet potato cultivars during simulated flood damage and storage. J. Amer. Soc. Hort. Sci. 107:674-677.

Couey, H.M. 1989. Heat treatment for control of postharvest diseases and insect pest of fruits. HortScience 24:198-202.

Couey, H.M. and C. Hayes. 1986. Quarantine procedure for Hawaiian papaya using fruit selection and two-stage hot water immersion. J. Econ. Entomol. 79:1307-1314.

Davis, D.D. 1980. Anaerobic metabolism and the production of organic acids, p. 588-611. In: D.D. Davis (cd.). The biochemistry of plants. A comprehensive treatise. vol. 2. Metabolism and respiration. Academic, New York.

Delate, K.M. and J.K. Brecht. 1989. Quality of tropical sweet potatoes exposed to controlled atmosphere treatments for postharvest insect control. J. Amer. Soc. Hort. Sci. 114:963-968.

Delate, K.M., J.K. Brecht, and J.A. Coffelt. 1990. Controlled atmosphere treatments for control of sweet potato weevil (Coleoptera curculionidae) in stored tropical sweet potatoes. J. Econ. Entomol. 83:461-465.

Evans, R.C. and M.O. Garraway. 1976. Effects of thiamine on ethanol and pyruvate production in Helminthosporium maydis. Plant Physiol. 57:812-816.

Gaunce, A.P., C.V.G. Morgan, and M. Meheriuk. 1982. Control of tree fruit insects with modified atmospheres, p. 383-390. In: D.G. Richardson and M. Meheriuk (eds.). Controlled atmospheres for storage and transport of perishable agricultural commodities. Timber Press, Beaverton, Ore.

Hoffman, N.E., A.F. Bent, and A.D. Hanson. 1986. Induction of lactate dehydrogenase isozymes by oxygen deficit in barley root tissue. Plant Physiol. 82:658-663.

Kader, A.A. 1986. Biochemical and physiological basis for effects of controlled and modified atmospheres on fruits and vegetables. Food Technol. 40(5):99-100, 102-104.

Kader, A.A. and L.L. Morris. 1977. Relative tolerance of fruits and vegetables to elevated $\mathrm{CO}_{2}$ and reduced $\mathrm{O}_{2}$ levels, p. 260-265. In:
D.H. Dewey (ed.). Controlled atmospheres for the storage and transport of perishable agricultural commodities. Proc. 2nd Natl. Controlled Atmosphere Res. Conf., Hort. Rpt. no. 28, Dept. Hort., Mich. State Univ., East Lansing.

Ke, D., H. van Gorsel, and A.A. Kader. 1990. Physiological and quality responses of 'Bartlett' pears to reduced $\mathrm{O}_{2}$ and enhanced $\mathrm{CO}_{2}$ levels and storage temperature. J. Amer. Soc. Hort. Sci. 115:435439.

Ripp, B.E. (ed.). 1984. Controlled atmosphere and fumigation in grain storage. Elsevier, New York.

Smilanick, J.L. and D.C. Fouse. 1989. Quality of nectarines stored in insecticidal low- $\mathrm{O}_{2}$ atmospheres at $5 \mathrm{C}$ and $15 \mathrm{C}$. J. Amer. Soc. Hort. Sci. 114:431-436.

Soderstorm, E.L. and D.G. Brandl. 1984. Low $\mathrm{O}_{2}$ atmosphere for postharvest insect control in bulk-stored raisins. J. Econ. Entomol. 77:440-445.

Soderstorm, E.L., P.D. Gander, J.L. Baritelle, K.N. de Lozano, and D. Brandl. 1984. Economic cost evaluation of a generated lowoxygen atmosphere as an alternative fumigant in the bulk storage of raisins. J. Econ. Entomol. 77:457-461.

Tiznado, M., E.M. Yahia, and L. Vazquez-Moreno. 1990. The tolerance of mango to insecticidal oxygen atmosphere. HortScience 25:1096. (Abstr.)

Yahia, E.M. and A.A. Kader. 1991. Physiological and biochemical responses of avocado fruits to $\mathrm{O}_{2}$ and $\mathrm{CO}_{2}$ stress. Plant Physiol. 96(Suppl):36. (Abstr.)

Yahia, E.M. D. Ke, and A.A. Kader. 1991. Responses of 'Bartlett' pears to insecticidal $\mathrm{O}_{2}$ and $\mathrm{CO}_{2}$ atmospheres. HortScience 26:734. (Abstr.)

Yahia, E.M., F. Medina, and M. Rivera. 1989. The tolerance of mango and papaya to atmospheres containing very high levels of $\mathrm{CO}_{2}$ and/ or very low levels of $\mathrm{O}_{2}$ as a possible insect quarantine control treatment, p. 77-89. In: J.K. Fellman (cd.). Fifth proceedings. vol. 2. Other commodities and storage recommendations. Intl. Controlled Atmosphere Res. Conf., 14-16 June 1989, Wenatchee, Wash.

Zee, F.T., M.S. Nishina, H.T. Chan Jr., and K.A. Nishijima. 1989. Blossom end defects and fruit fly infestation in papayas following hot water quarantine treatment. HortScience 24:323-325. 